\title{
GENE EXPRESSION PROFILING IN BONE TISSUE OF OSTEOPOROTIC MICE
}

\author{
Iva ORLIĆ1 , Fran BOROVEČKI ${ }^{2}$, Petra ŠIMIĆ ${ }^{1}$, and Slobodan VUKIČEVIĆ ${ }^{1}$ \\ Department of Anatomy, Medical School University of Zagreb ${ }^{1}$, Center for Functional Genomics, University \\ Hospital, Medical School University of Zagreb², Zagreb, Croatia
}

Received in December 2006

Accepted in January 2007

\begin{abstract}
Ovaricetomized (OVX) animals represent an optimal model to investigate bone loss in osteoporosis. To further elucidate the underlying mechanisms of decreased bone formation and increased bone resorption following OVX, we conducted gene expression profiling experiments using bone samples of ovariectomized C57BL/6J mice. Following OVX, genes involved in immune response, cell cycle regulation, growth, apoptosis and bone resorption were upregulated, while genes that are important for regular cell processes, mitosis, metabolism of carbohydrates, extracellular matrix structure, angiogenesis, skeletal development and morphogenesis were downregulated. Among bone specific genes we observed upregulation of interleukin 7 (IL-7), IL-7 receptor and matrix metallopeptidase 8 , while genes such as transforming growth factor-beta 3, procollagen type I and procollagen type VI exhibited marked decrease in expression. We also observed downregulation of two genes, parathyroid hormone receptor 1 and WD repeat domain 5, that are involved in skeletal development but were not previously reported to be altered in osteoporosis. We further performed gene set enrichment analysis (GSEA) in order to calculate enrichment of pathways specifically altered in murine bones following ovariectomy.

In conclusion, OVX greatly influences expression of various genes involved in diverse biological processes confirming the notion that numerous pathways play an important role in pathophysiology of osteoporosis.
\end{abstract}

KEY WORDS: bone resorption, microarray, osteoporosis, ovariectomy

Osteoporosis is a skeletal disease characterized by low bone mass and microarchitectural deterioration with a resulting increase in bone fragility and subsequent susceptibility to fracture (1). One of the most important traits of osteoporosis is low bone mineral density (BMD) (2). The decrease in bone mass observed in osteoporosis stems from the imbalance in bone remodeling where bone resorption by osteoclasts exceeds osteoblastic bone formation. In healthy adults, skeleton bone remodeling is responsible for the maintenance of the bone volume and architecture. Cellular interactions occurring within a remodeling cycle are divided into four main events: activation, resorption, reversal, and formation (3). In the state of estrogen deficiency there is a remodeling imbalance with a substantial increase in bone turnover. This imbalance leads to the progressive loss of trabecular and cortical bone, partly due to increased osteoclastogenesis.

In the last 20 years the expression of genes involved in bone metabolism and particularly in the onset and development of osteoporosis has been extensively studied (4). Previous studies have shown that osteoporosis involves complex control mechanisms which involve multiple factors, such as hormones, cytokines, various receptors, etc. Numerous genes are known to be differentially expressed in postmenopausal women with lower BMD and osteoporotic fractures as 
compared to postmenopausal women with normal bone density. These include interleukin $1 \alpha$ (IL-1 $\alpha$ ), IL- $1 \beta$ and IL- 6 which were shown to be significantly expressed in bone samples of osteoporotic individuals (5). Furthermore, three genes with putative role in bone metabolism, namely CCR3 (chemokine receptor 3), HDC (histidine decarboxylase, i.e. the histamine synthesis enzyme), and GCR (glucocorticoid receptor) were upregulated in circulating monocytes of subjects with low BMD (6). In addition, increased production of IL-1 and tumour necrosis factor $\alpha$ (TNF- $\alpha$ ) has been observed in circulating mononuclear cells in women with postmenopausal osteoporosis $(7,8)$.

Because of the complex etiology of osteoporosis, which entails a large number of genes both in its onset and progression, microarray technique represents a powerful tool for unraveling of the intricate mechanisms involved. Ovariectomized (OVX) animals represent an optimal animal model to investigate bone loss in osteoporosis (9). Previous gene expression profiling experiments performed on femurs of OVX and vehicle-treated rats, revealed a specific profile of 644 differentially expressed genes when compared to sham control rats (10). At 40 days following OVX there was an increase in expression of genes associated with bone formation (Col1a2, Col5a1, osteocalcin, osteonectin and decorin), while osteoclastic genes (i.e., cathepsin K, tartrate resistant acid phosphatase and calcitonin receptor) were either not expressed above the background level or were not significantly changed by OVX (10).

We have previously shown that OVX in mice of the C57BL/6J strain leads to trabecular and cortical bone loss at both axial and appendicular sites, as indicated by lower BMD values of the femur, tibia and lumbar spine $(11,12)$. In order to further elucidate changes in transcription caused by OVX, we have performed microarray gene expression profiling experiments using bone samples of sham and OVX mice.

\section{MATERIALS AND METHODS}

\section{Animals}

Wild type C57BL/6J mice were purchased from Charles River, Budapest, Hungary. Animals were housed in groups of five in stainless-steel wire mesh-bottomed cages. Food (2014S rat/mice diet, Harlan Teklad, Winhelmann $\mathrm{GmbH}$ ) and water were available ad libitum. Animals were maintained in accordance with the NIH Guide for the Care and Use of Laboratory Animals (13), and protocols were approved by Institutional Ethics Committee and Ministry of Science Grant Review Committee. At three months of age in sham mice $(n=5)$ ovaries were exteriorized but replaced intact, while bilateral OVX with dorsal approach was performed in the remaining mice $(n=5)$. OVX animals were left untreated for 3 weeks following surgery to await the development of osteoporosis when they were sacrificed.

\section{RNA isolation and gene expression profiling}

Total RNA was extracted from whole murine femur samples using TRIzol reagent (Invitrogen, Carlsbad, CA, USA) and RNeasy ${ }^{\circledR}$ Mini Kit (Qiagen, Hilden, Germany) according to manufacturer's protocol. The quality of total RNA was analyzed using the RNA 6000 Nano LabChip kit on a 2100 Bioanalyzer (Agilent Technologies, Palo Alto, CA, USA). Microarray analysis was performed using Mouse Genome 430 2.0 GeneChips (Affymetrix, Santa Clara, CA, USA), which contains 45000 25-mer probe sets. The RNA was processed using the standard Affymetrix protocol. Briefly, using One-Cycle cDNA Synthesis kit and IVT Labeling kit (Affymetrix), $5 \mu \mathrm{g}$ of total RNA were transcribed into biotin-labeled cRNA. Labeled cRNA probe was hybridized overnight to Mouse Genome 430 2.0 GeneChips (Affymetrix). Following hybridization, arrays were washed, fluorescently tagged and scanned, using the Affymetrix GeneChip Scanner 3000. Usual quality measures and normalization for the Affymetrix GeneChip (3'/5' ratios and trimmed mean normalization) were used in the experiments. All arrays were run in the same core facility at Center for Functional Genomics, School of Medicine, University of Zagreb.

\section{Statistical analysis}

Gene Chip data was analyzed using the Affymetrix GCOS 1.2 software, Excel, Access, DChip and GeneSpring 7.2 software. The data was normalized and filtered according to expression level. The Student T-test was used to determine significant changes in gene expression between sham and OVX groups of animals. Significant genes were selected according to cut-off values of $\mathrm{P}<0.05$ and fold change $<0.6$ and $>1.8$.

\section{Gene Set Enrichment Analysis}

In an effort to test the functional correlation of gene sets that might be systemically altered in OVX 
mice, we applied a statistical method called Gene Set Enrichment Analysis (14). GSEA was developed for analysis of genome-wide expression experiments, using the principle of gene-ranking based on the correlation between their expression and the class distinction by applying the signal-to-noise ratio metric. Using the freely available GSEA-P software and a set of 522 predefined functional groups, we performed GSEA on a database of 10 gene expression profiles of sham and OVX mice.

\section{RESULTS}

\section{Differential expression of genes following OVX}

After filtering probe sets with signal below the target intensity of 100, 9423 probe sets were further analyzed. The transcripts were further divided into upregulated (fold change higher than 1.8) and downregulated (fold change lower than 0.6), while transcripts with fold change between 0.6 and 1.8 were left out of the subsequent analysis. OVX mice exhibited considerably higher number of downregulated transcripts, with 137 upregulated and 348 downregulated genes.

Among the transcripts significantly over-expressed following OVX, several functional groups and pathways were significantly represented. Most notably, the upregulated transcripts included genes involved in bone resorption, such as interleukin 7, intreleukin 7 receptor and matrix metallopeptidase 8 (Table 1). Genes involved in immune response, for example eosinophil peroxidase, proteoglycan 3 , major histocompatibility complex (MHC) class I H2$\mathrm{L}-\mathrm{d}$, chemokine (C-C motif) receptor $2, \mathrm{MHC}$ class I H-2Ds and histocompatibility $2 \mathrm{M}$ region locus 3 were significantly upregulated as well. It is important to stress that Smad 4, a well-described downstream molecule in the BMP and TGF-beta signaling also exhibited significantly increased expression, implicating activation of mechanisms involved in bone formation. Other upregulated transcripts included genes involved in growth and apoptosis, such as growth arrest specific 5, S-phase kinase-associated protein 2 (p45), and apoptosis inhibitor 5. Processes like nucleic acid binding (eosinophil-associated ribonuclease 1), regulation of transcription (signal transducer and activator of transcription 1) and protein transport (sorting nexin 5) were also affected by OVX.

Genes involved in skeletal development and morphogenesis, such as receptor-like tyrosine kinase, parathyroid hormone receptor 1 and WD repeat domain 5 were among the significantly decreased transcripts. It is also important to stress that the latter two genes have not been shown previously to be significantly decreased following OVX. Genes that code for proteins important in extracellular matrix, namely procollagen type I $\alpha 1$, peptidoglycan recognition protein 1 and procollagen type $\mathrm{VI} \alpha 2$, were also decreased in expression. Vascular endothelial growth factor $B$ was downregulated by 1,7 fold in bone tissue of OVX mice indicating impaired vascularization following ovariectomy.

Overall, regular cellular processes, such as rRNA processing, transcription, protein production, binding and modification, represented by decreased expression of nucleoplasmin 3, RNA polymerase II, TSC22 domain family member 1 , triadin and thyroid hormone receptor interactor 12 , were adversely affected by OVX. Cell cycle was also deregulated as indicated by decreased expression of genes involved in mitosis and cell cycle regulation, namely tubulin $\beta 5$, cyclin A2, interferon-related developmental regulator 2, cyclin E1, transforming growth factor -beta 3, cyclin A2 and cyclin D3. The metabolism of carbohydrates was impaired as well, mainly through inhibition of glycolysis and fructosamine metabolism (fructosamine 3 kinase, enolase $3 \beta$ and phosphofructokinase) (Table 2).

Gene Set Enrichment Analysis reveals activation of bone resorption in OVX mice

To further elucidate the underlying mechanisms of bone metabolism following OVX we calculated the enrichment scores (ES) of 522 predefined gene sets (MSigDB1, Broad Institute, Boston, USA) containing genes involved in specific metabolic and signaling pathways (14). Estimated statistical significance (nominal $P$ value) of the ES was also calculated by using an empirical phenotype-based permutation test procedure that preserves the complex correlation structure of the gene expression data. Nominal $P$ value of $P<0.05$ was taken as a cut-off value in the analysis.

Using GSEA we tried to identify functional sets specifically enriched in ovariectomized animals (Figure 1). The SHAM $>\mathrm{OVX}$ analysis revealed significant enrichment of insulin-like growth factor-1 (IGF-1) related pathways, including IGF-1 receptor pathway, insulin signaling pathway, glycogen metabolism, as well as glycolysis and gluconeogenesis. Cell cycle and vascular endothelial growth factor gene sets were 
Table 1 Upregulated genes following OVX

\begin{tabular}{|c|c|c|c|c|c|c|}
\hline $\begin{array}{l}\text { Biological process/ } \\
\text { molecular function }\end{array}$ & $\begin{array}{c}\text { Gene Bank } \\
\text { Accession No. }\end{array}$ & Probe set ID & Gene Title & Symbol & $\begin{array}{l}\text { Fold } \\
\text { Change }\end{array}$ & $P$ value \\
\hline Nucleic acid binding & NM_007894.1 & 1421802_at & $\begin{array}{l}\text { eosinophil-associated } \\
\text { ribonuclease } 1\end{array}$ & Ear1 & 9.35 & 0.0003 \\
\hline $\begin{array}{l}\text { Response to oxidative } \\
\text { stress }\end{array}$ & NM_007946.1 & 1449136_at & eosinophil peroxidase & Epx & 5.82 & 0.0130 \\
\hline Immune response & NM_016914.1 & 1449924_at & proteoglycan 3 & Prg3 & 4.61 & 0.0026 \\
\hline Immune response & M33151.1 & 1426324_at & $\begin{array}{l}\text { histocompatibility } \\
2 \mathrm{D} \text { region locus } 1\end{array}$ & MHC H2Ld & 3.83 & 0.0387 \\
\hline Immune response & NM_008920.1 & 1422873_at & $\begin{array}{c}\text { proteoglycan } 2 . \\
\text { bone marrow }\end{array}$ & Prg2 & 3.31 & 0.0009 \\
\hline Growth arrest & ВС004622.1 & 1424843_a_at & growth arrest specific 5 & Gas5 & 2.75 & 0.0443 \\
\hline $\begin{array}{l}\text { Inflammatory } \\
\text { response }\end{array}$ & NM_009915.1 & 1421187_at & $\begin{array}{c}\text { chemokine (C-C motif) } \\
\text { receptor } 2\end{array}$ & Ccr2 & 2.72 & 0.0118 \\
\hline Chemotaxis & NM_007895.2 & 1449846_at & $\begin{array}{l}\text { eosinophil-associated } \\
\text { ribonuclease } 2\end{array}$ & Ear2 & 2.47 & 0.0021 \\
\hline $\begin{array}{l}\text { Regulation of cell } \\
\text { cycle }\end{array}$ & NM_013787.1 & 1418969_at & $\begin{array}{l}\text { S-phase kinase- } \\
\text { associated protein } \\
2(\mathrm{p} 45)\end{array}$ & Skp2 & 2.38 & 0.0204 \\
\hline Antigen presentation & M34962.1 & 1451683_x_at & $\begin{array}{l}\text { histocompatibility } \\
\text { 2. L region }\end{array}$ & MHC H2Dr & 2.34 & 0.0489 \\
\hline Growth factor activity & NM_022024.2 & 1419193_a_at & $\begin{array}{l}\text { glia maturation factor. } \\
\text { gamma }\end{array}$ & Gmfg & 2.32 & 0.0003 \\
\hline $\begin{array}{l}\text { Regulation of } \\
\text { transcription }\end{array}$ & BM239586 & 1420915_at & $\begin{array}{c}\text { signal } \\
\text { transducer\&activator } \\
\text { of transcription } 1\end{array}$ & Stat1 & 2.16 & 0.0477 \\
\hline IL receptor activity & NM_008372.2 & 1448575_at & interleukin 7 receptor & $\mathrm{II} 7 \mathrm{r}$ & 2.12 & 0.0499 \\
\hline Bone resorption & BG069762 & 1436861_at & interleukin 7 & II7 & 1.99 & 0.0244 \\
\hline $\begin{array}{l}\text { Filament-based } \\
\text { process }\end{array}$ & AV147875 & 1438118_x_at & vimentin & Vim & 1.99 & 0.0359 \\
\hline Immune response & NM_013819 & 1421358_at & $\begin{array}{l}\text { histocompatibility } 2 \mathrm{M} \\
\quad \text { region locus } 3\end{array}$ & H2-M3 & 1.97 & 0.0293 \\
\hline Protein transport & NM_024225.1 & 1417646_a_at & sorting nexin 5 & Snx5 & 1.85 & 0.0096 \\
\hline Morphogenesis & NM_008540.2 & 1422485_at & MAD homolog 4 & Smad4 & 1.82 & 0.0440 \\
\hline Collagen catabolism & NM_008611.1 & 1449366_at & matrix metallopeptidase 8 & Mmp8 & 1.80 & 0.0086 \\
\hline Apoptosis & AV118744 & 1439214_a_at & apoptosis inhibitor 5 & Api5 & 1.80 & 0.0039 \\
\hline
\end{tabular}

Differential expression of genes in femurs of WT sham vs. OVX animals. Genes were ranked according to the fold change. The fold changes were calculated based on expression values of 5 independent biological replicates per group. 


\begin{tabular}{|c|c|c|c|c|c|c|}
\hline $\begin{array}{l}\text { Biological process/ } \\
\text { molecular function }\end{array}$ & $\begin{array}{c}\text { Gene Bank } \\
\text { Accession No. }\end{array}$ & Probe set ID & Gene Title & Symbol & $\begin{array}{l}\text { Fold } \\
\text { Change }\end{array}$ & $P$ value \\
\hline $\begin{array}{l}\text { rRNA processing, protein } \\
\text { folding }\end{array}$ & BB811478 & 1423522_at & Nucleoplasmin 3 & Npm3 & $0.21(-4.76)$ & 0.0032 \\
\hline Transcription & U37500.1 & 1426242_at & RNA polymerase II & Polr2a & $0.29(-3.51)$ & 0.0037 \\
\hline Mitotic spindle assembly & BG064086 & 1455719_at & tubulin, $\beta 5$ & Tubb5 & $0.31(-3.46)$ & 0.0177 \\
\hline Mitosis & NM_009828.1 & 1417910_at & cyclin A2 & Ccna2 & $0.39(-2.54)$ & 0.0022 \\
\hline Fructosamine metabolism & NM_022014.2 & 1418311_at & fructosamine 3 kinase & Fn3k & $0.42(-2.41)$ & 0.0317 \\
\hline Calcium ion binding & NM_013473.1 & 1417732_at & annexin A8 & Anxa8 & $0.43(-2.35)$ & 0.0046 \\
\hline $\begin{array}{l}\text { Cell proliferation\&different } \\
\text { iation }\end{array}$ & NM_025903.1 & 1451016_at & $\begin{array}{l}\text { interferon-related } \\
\text { development } \\
\text { regulator } 2\end{array}$ & Ifrd2 & $0.45(-2.21)$ & 0.0056 \\
\hline Skeletal morphogenesis & M98547.1 & $\begin{array}{l}1451789 \\
\text { a_at }\end{array}$ & $\begin{array}{l}\text { receptor-like tyrosine } \\
\text { kinase }\end{array}$ & Ryk & $0.48(-2.06)$ & 0.0023 \\
\hline Regulation of cell cycle & NM_007633.2 & 1416492_at & cyclin E1 & Cone1 & $0.52(-1.93)$ & 0.0078 \\
\hline Glycolysis & NM_007933.1 & 1417951_at & enolase $3, \beta$ muscle & Eno3 & $0.53(-1.90)$ & 0.0083 \\
\hline Regulation of transcription & AU016382 & 1433899_ & $\begin{array}{l}\text { TSC22 domain family, } \\
\text { member } 1\end{array}$ & Tsc22d1 & $0.53(-1.89)$ & 0.0097 \\
\hline ECM structural molecule & BI794771 & 1455494 & $\begin{array}{l}\text { procollagen, } \\
\text { type I, } \alpha 1\end{array}$ & Colla1 & $0.53(-1.88)$ & 0.0080 \\
\hline $\begin{array}{l}\text { Cell proliferation, cell } \\
\text { growth }\end{array}$ & ВС014690.1 & 1417455_at & $\begin{array}{l}\text { transforming growth } \\
\text { factor, } \beta 3\end{array}$ & Tgfb3 & $0.54(-1.85)$ & 0.0294 \\
\hline Protein binding & AF223417.1 & $\begin{array}{c}1426144 \\
x_{-} \text {at }\end{array}$ & triadin & Trdn & $0.54(-1.84)$ & 0.0251 \\
\hline Calcium ion binding & NM_013469.1 & 1418468_at & annexin A11 & Anxa11 & $0.55(-1.80)$ & 0.0105 \\
\hline Skeletal development & ВC013446.1 & 1417092_at & $\begin{array}{l}\text { parathyroid hormone } \\
\text { receptor } 1\end{array}$ & Pthr1 & $0.57(-1.75)$ & 0.0160 \\
\hline Protein modification & ВС004085.1 & $\begin{array}{c}1423898 \_ \\
\text {a_at }\end{array}$ & $\begin{array}{l}\text { thyroid hormone } \\
\text { receptor interactor } 12\end{array}$ & Trip12 & $0.58(-1.75)$ & 0.0148 \\
\hline Regulation of cell cycle & X75483.1 & 1417911_at & cyclin A2 & Ccna2 & $0.58(-1.72)$ & 0.0236 \\
\hline Skeletal development & NM_080848.1 & 1416581_at & WD repeat domain 5 & Wdr5 & $0.58(-1.71)$ & 0.0488 \\
\hline Angiogenesis & U48800.1 & $\begin{array}{c}1451803 \\
\text { a_at }\end{array}$ & $\begin{array}{l}\text { vascular endothelial } \\
\text { growth factor B }\end{array}$ & Vegfb & $0.59(-1.70)$ & 0.0003 \\
\hline Regulation of glycolysis & NM_021514.2 & 1416780_at & $\begin{array}{l}\text { phosphofructokinase, } \\
\text { muscle }\end{array}$ & Pfkm & $0.60(-1.68)$ & 0.0140 \\
\hline Regulation of cell cycle & NM_007632.1 & 1415907_at & cyclin D3 & Cond3 & $0.60(-1.66)$ & 0.0025 \\
\hline ECM structural molecule & BI455189 & $\begin{array}{c}1426947 \\
x_{-} \text {at }\end{array}$ & $\begin{array}{l}\text { procollagen, } \\
\text { type } \mathrm{VI}, \alpha 2\end{array}$ & Col6a2 & $0.60(-1.66)$ & 0.0101 \\
\hline Peptidoglycan catabolism & NM_009402.2 & 1449184_at & $\begin{array}{l}\text { peptidoglycan } \\
\text { recognition protein } 1\end{array}$ & Pglyrp1 & $0.60(-1.66)$ & 0.0353 \\
\hline
\end{tabular}

Differential expression of genes in femurs of WT sham vs. OVX animals. Genes were ranked according to the fold change. The fold changes were calculated based on expression values of 5 independent biological replicates per group. 
also highly enriched in SHAM animals, indicating increased cell proliferation and vascularization prior to ovariectomy. The reciprocal OVX > SHAM comparison revealed increased enrichment of fatty acid metabolism, IL-12 and tumor necrosis factor receptor 2 (TNFR2) pathways, indicating increased cytokine production in ovariectomized animals. Enrichment of caspase pathway might indicate increased rate of apoptosis in these animals. Furthermore, proteasome pathway was also significantly enriched following OVX, pointing to increased protein degradation.

\section{DISCUSSION}

Although widely studied, complex etiology of osteoporosis has still not been fully elucidated. Ovariectomy of mature mice induces cancellous and cortical bone loss in axial and appendicular sites. Since these changes mimic processes observed in postmenopausal women (15), this model has been widely used to study etiology of osteoporosis (9). In this study, we identified genes that are altered following OVX and could account for observed bone loss.

Most notably, at 21 days following OVX we observed upregulation of genes involved in bone resorption, suggesting that this time point is very close to the initial peak of osteoclastic activity. Among the genes with increased gene expression, we have observed upregulation of interleukin 7 (IL-7) and

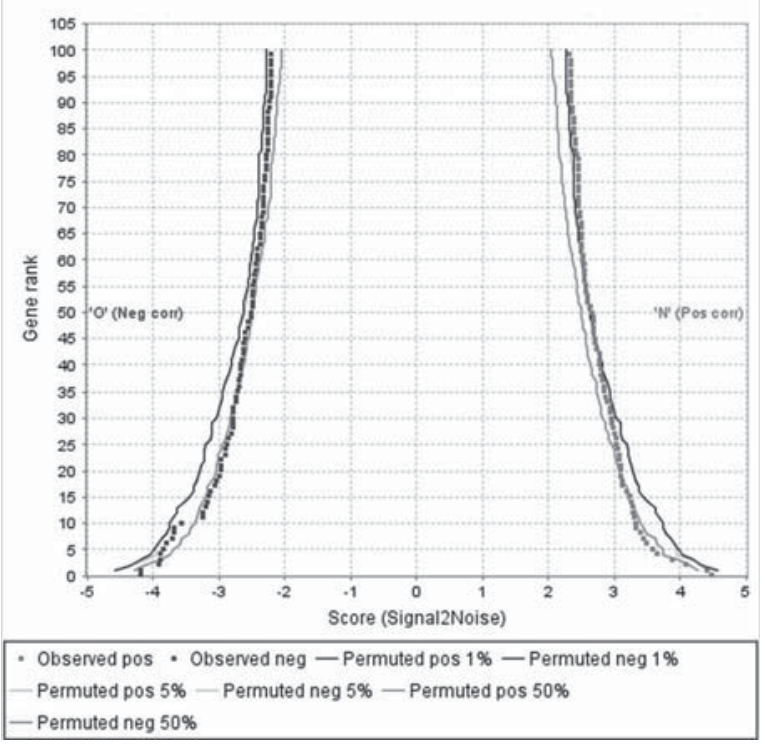

A
IL-7 receptor. IL-7 is a lymphopoietic cytokine that promotes osteoclastogenesis by upregulating key $\mathrm{T}$ cell-derived osteoclastogenic cytokines, including receptor activator of NF-KB ligand (RANKL), and by increasing the number of early precursors of the $B$ cell lineage in the bone marrow, a population that has been suggested to have the capacity to differentiate into osteoclasts $(16,17)$. IL-7 receptor knockout mice display increased bone volume and bone mineral density (16).

Another evidence confirming increased bone resorption in bone samples of OVX mice is elevated expression of Mmp-8, which has been previously reported as increased in bone marrow stromal cells from osteoporotic rats (18). Mmp-8 is expressed in a wide range of cells mainly in the course of different inflammatory conditions. Besides being an efficient collagen degrading protease (collagen type I $>$ type III > type II), Mmp-8 also cleaves a wide range of non-collagenous substrates, such as serine protease inhibitors and several chemokines (19).

Following OVX we observed a significant upregulation of various genes that are involved in immune response (eosinophil peroxidase, proteoglycan 3, MHC class I H2-L-d, proteoglycan 2, chemokine (C-C motif) receptor 2, MHC class I H-2Ds and histocompatibility 2 M region locus 3 ), which supports the notion that in estrogen deficient state upregulation of molecules involved in immune response induces bone loss (20). It has been previously shown that

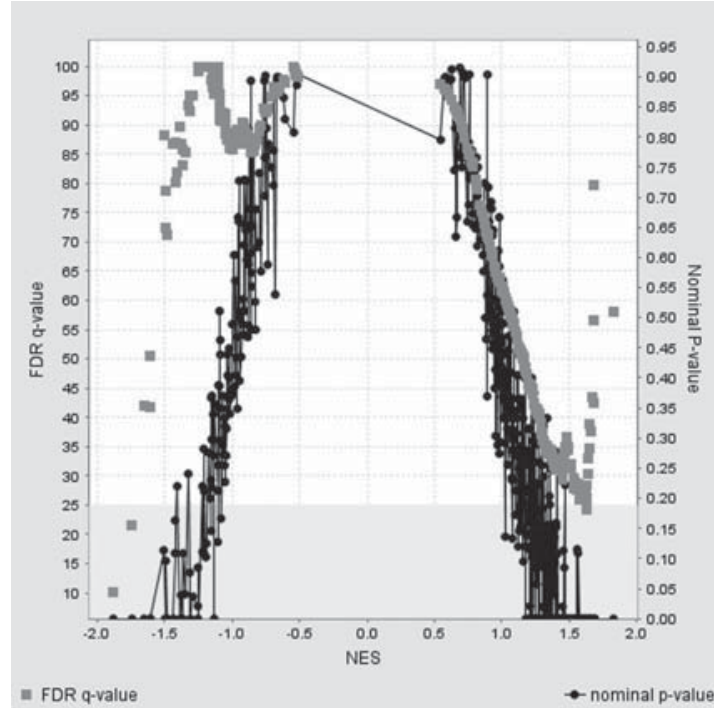

B

Figure 1 Gene set enrichment analysis (GSEA) reveals pathways significantly altered in ovariectomized animals. A) The "butterfly plot" showing the observed correlation, as well as negative and positive permuted correlation, for the top 100 genes. B) Plot of $p$ values versus normalized enrichment scores, showing a higher proportion of significantly enriched gene sets in the sham group of animals. 
OVX upregulates $T$ cell TNF production primarily by increasing the number of TNF-producing T cells (21) and that due to the elevated TNF production, bone resorption is increased.

Among genes involved in immune response we observed upregulation of chemokine receptor 2 (Ccr2). It has been suggested that upregulation of another chemokine receptor, CCR3 in circulating monocytes of individuals with low BMD may facilitate both the access of monocytes to the bone microenvironment and their subsequent differentiation into osteoclasts (6). Since it was shown that chemokine receptors CCR2b and CCR4 were potently induced by RANKL (22), we suggest that increased expression of $\mathrm{C} c \mathrm{C} 2$ was rather a consequence of elevated RANKL production due to increased bone remodeling, than a direct cause of increased bone resorption.

Gene set enrichment analysis was highly concordant with observed differentially expressed genes. Among the pathways enriched in the ovariectomized animals, gene sets involved in bone resorption, such as fatty acid metabolism, IL-12 and tumor necrosis factor receptor 2 (TNFR2) pathways, were significantly enriched. Other pathways, such as caspase and proteasome pathways, were also indicative of increased catabolism, and in accordance with individual gene changes observed.

In our study we have also observed downregulation of transforming growth factor-beta 3 (TGF-beta 3). TGF-beta and IL-7 inversely regulate each other's production. The reduction in TGF-beta signaling, characteristic of estrogen deficiency, may serve to further stimulate IL-7 production, thus driving the cycle of osteoclastogenic cytokine production and bone wasting (20). It was shown that ovariectomy enhances the production of the osteoclastogenic cytokine IL-7, and that its neutralization in vivo prevents OVX-induced bone loss (23). It has also been reported that OVX significantly reduces mRNA expression level of TGF-beta in bone (24) and that TGF-beta 3 inhibits osteoclast differentiation, suggesting its role in estrogen-mediated bone maintenance (25). We have observed an upregulation of both IL-7 and IL-7 receptor, and downregulation of TGF-beta 3 confirming strong influence of IL-7 on bone resorption $(16,17)$, effect of TGF-beta 3 decrease on pronounced osteoclast differentiation (25) and IL-7 - TGF-beta dependent cycle (20).

Although it was reported that OVX induces an increase in expression of bone formation associated genes (Col1a2, Col5a1, osteocalcin, osteonectin and decorin) (10), we observed a downregulation of
Col1a1 and Col6a2. These data are inconsistent most likely because of different time points of RNA isolation (40 days compared to 21 days) resulting in different phases of bone remodeling.

In this study we have observed downregulation of two genes (Pthr1 and Wdr5) that are known to be important for skeletal development, but alternation of their expression in osteoporosis was not previously reported. Pthr 1 mediates most of the traditional actions of PTH in mineral ion homeostasis and is critical to its actions on bone and kidney (26), while Wdr5 accelerates osteoblast and chondrocyte differentiation in vitro, and is developmentally expressed in osteoblasts, as well as in proliferating and hypertrophic chondrocytes (27). Observed reduction in expression of Pthr 1 and Wdr5 in OVX mice suggests impaired activity of endogenous PTH on bone tissue and decreased osteoblast differentiation resulting in imbalanced bone remodeling.

\section{CONCLUSION}

We have shown that OVX greatly influences various genes involved in diverse biological processes, confirming the notion that numerous pathways play an important role in the pathophysiology of osteoporosis (23). Specifically, we discovered novel downregulation of two genes, Pthr1 and Wdr5, which are involved in the skeletal development but were not previously reported to be altered in osteoporosis.

\section{REFERENCES}

1. Cummings SR, Melton LJ. Epidemiology and outcomes of osteoporotic fractures. Lancet 2002;359:1761-7.

2. Hui SL, Slemenda CW, Johnston CC. Baseline measurement of bone mass predicts fracture in white women. Ann Intern Med 1989;111:355-61.

3. Raisz LG. Physiology and pathophysiology of bone remodeling. Clin Chem 1999;45:1353-8.

4. Dvornyk V, Recker RR, Deng HW. Gene expression studies of osteoporosis: implications for microarray research. Osteoporos Int 2003;146:451-61.

5. Ralston SH. Analysis of gene expression in human bone biopsies by polymerase chain reaction: evidence for enhanced cytokine expression in postmenopausal osteoporosis. J Bone Miner Res. 1994;96:883-90.

6. Liu YZ, Dvornyk V, Lu Y, Shen H, Lappe JM, Recker RR, Deng HW. A novel pathophysiological mechanism for osteoporosis suggested by an in vivo gene 
expression study of circulating monocytes. J Biol Chem 2005;280:29011-6.

7. Pacifici R, Rifas L, Teitelbaum S, Slatopolsky E, McCracken R, Bergfeld M, Lee W, Avioli LV, Peck WA. Spontaneous release of interleukin 1 from human blood monocytes reflects bone formation in idiopathic osteoporosis. Proc Natl Acad Sci USA 1987;84:461620.

8. Pacifici R, Brown C, Puscheck E, Friedrich E, Slatopolsky E, Maggio D, McCracken R, Avioli LV. Effect of surgical menopause and estrogen replacement on cytokine release from human blood mononuclear cells. Proc Natl Acad Sci USA 1991;88:5134-8.

9. Kimmel DB. Animal models in osteoporosis research. In: Bilezikian JP, Raisz LG, Rodan GA, editors. Principles of Bone Biology. $2^{\text {nd }}$ ed. San Diego, San Francisco, New York, Boston, London, Sydeny, Tokyo: Academic Press; 2002. p. 1635-55.

10. Helvering LM, Liu R, Kulkarni NH, Wei T, Chen P, Huang S, Lawrence F, Halladay DL, Miles RR, Ambrose EM, Sato M, Ma YL, Frolik CA, Dow ER, Bryant HU, Onyia JE. Expression profiling of rat femur revealed suppression of bone formation genes by treatment with alendronate and estrogen but not raloxifene. Mol Pharmacol 2005;685:1225-38.

11. Simic P, Buljan-Culej J, Orlic I, Borovecki F, Vukicevic S. BMP-6 restores bone in osteoporotic aged rats and, unlike estradiol and PTH, restores trabecular bone in ovariectomized BMP-6 knockout mice. J Bone Miner Res 2005;20:S8.

12. Borovecki F, Grasser WA, Orlic I, Paralkar VM, Vukicevic S. BMP-6 induces new bone formation in ovariectomized mice and enhances differentiation of primary human osteoblasts through activation of IGF-1 and EGF pathways. Calcif Tissue Int 2006;78: S71-2.

13. National Academy of Sciences, Institute of Laboratory Animal Resources Commission on Life Sciences. Guide for the Care and Use of Laboratory Animals [displayed $15^{\text {th }}$ December 2006]. Available at http://www.nap. edu/readingroom/ books/labrats/

14. Subramanian A, Tamayo P, Mootha VK, Mukherjee S, Ebert BL, Gillette MA, Paulovich A, Pomeroy SL, Golub TR, Lander ES, Mesirov JP. Gene set enrichment analysis: a knowledge-based approach for interpreting genome-wide expression profiles. Proc Natl Acad Sci USA 2005;102:15545-50.

15. Turner RT, Riggs BL, and Spelsberg TC. Skeletal effects of estrogen. Endocrine Rev 1994;15:275-300.

16. Miyaura C, Onoe Y, Inada M, Maki K, Ikuta K, Ito M, Suda T. Increased B-lymphopoiesis by interleukin 7 induces bone loss in mice with intact ovarian function: similarity to estrogen deficiency. Proc Natl Acad Sci USA 1997;94:9360-5.

17. Hofmeister R, Khaled AR, Benbernou N, Rajnavolgyi E, Muegge K, Durum SK. Interleukin-7: physiological roles and mechanisms of action. Cytokine Growth Factor Rev 1999;10:41-60.

18. Xiao Y, Fu H, Prasadam I, Yang YC, Hollinger JO. Gene expression profiling of bone marrow stromal cells from juvenile, adult, aged and osteoporotic rats: With an emphasis on osteoporosis. Bone. 2006;40(3):70015.

19. Van Lint P, Libert C. Matrix metalloproteinase-8: cleavage can be decisive. Cytokine Growth Factor Rev 2006; 17:217-23.

20. Weitzmann MN, Pacifici R. Estrogen deficiency and bone loss: an inflammatory tale. $\mathrm{J}$ Clin Invest 2006;116:1186-94.

21. Roggia C, Gao Y, Cenci S, Weitzmann MN, Toraldo G, Isaia G, Pacifici R. Up-regulation of TNF-producing T cells in the bone marrow: a key mechanism by which estrogen deficiency induces bone loss in vivo. Proc Natl Acad Sci USA 2001;98:13960-5.

22. Kim MS, Magno CL, Day CJ, Morrison NA. Induction of chemokines and chemokine receptors CCR2b and CCR4 in authentic human osteoclasts differentiated with RANKL and osteoclast like cells differentiated by MCP-1 and RANTES. J Cell Biochem 2006;973:5128.

23. Weitzmann MN, Roggia C, Toraldo G, Weitzmann L, Pacifici R. Increased production of IL-7 uncouples bone formation from bone resorption during estrogen deficiency. J Clin Invest 2002;110:1643-50.

24. Finkelman RD, Bell NH, Strong DD, Demers LM, Baylink DJ. Ovariectomy selectively reduces the concentration of transforming growth factor beta in rat bone: implications for estrogen deficiency-associated bone loss. Proc Natl Acad Sci USA 1992;89:121903.

25. Yang NN, Bryant HU, Hardikar S, Sato M, Galvin RJ, Glasebrook AL, Termine JD. Estrogen and raloxifene stimulate transforming growth factor-beta 3 gene expression in rat bone: a potential mechanism for estrogen- or raloxifene-mediated bone maintenance. Endocrinology 1996;137:2075-84.

26. Potts JT. Parathyroid hormone: past and present. J Endocrinol 2005;183:311-25.

27. Gori F, Friedman LG, Demay MB. Wdr5, a WD-40 protein, regulates osteoblast differentiation during embryonic bone development. Dev Biol 2006;295:498506. 


\section{Sažetak}

\section{ANALIZA EKSPRESIJE GENA U KOŠTANOM TKIVU OSTEOPOROTIČNIH MIŠEVA}

Osteoporoza je najčešća metabolička bolest kostiju, obilježena smanjenom koštanom masom i poremećenom koštanom mikroarhitekturom. Prikladan životinjski model za istraživanje osteoporoze su ovarijektomirani miševi. Kako bismo pobliže istražili mehanizme smanjene koštane formacije i pojačane koštane razgradnje nakon ovarijektomije, proveli smo pokuse ekspresijskog profiliranja koristeći se uzorcima kostiju ovarijektomiranih miševa soja C57BL/6J. Nakon ovarijektomije pojačava se izražaj gena uključenih u imunološki odgovor, regulaciju staničnog ciklusa, apoptozu i koštanu razgradnju, dok se ekspresija gena bitnih za mitozu, metabolizam ugljikohidrata, razvoj kosti, strukturu izvanstaničnog matriksa i angiogenezu smanjuje. Od koštano specifičnih gena, interleukin 7 (IL-7), receptor za IL-7 i matriks metalopeptidazu 8 imali su pojačan izražaj, dok je za transformirajući čimbenik rasta -beta 3, prokolagen tipa I i tipa VI uočen smanjen genski izražaj. Također smo otkrili smanjen izražaj dvaju gena, i to receptora 1 za paratireoidni hormon i WD ponavljajuću domenu 5, koji su bitni za koštani razvoj, a promjena njihove regulacije nije do sada primijećena u osteoporozi. Kako bismo dodatno istražili obogaćenost pojedinih funkcionalnih skupina gena u kostima ovarijetkomiranih životinja, podatke smo analizirali s pomoću algoritma gene set enrichment analysis (GSEA).

Zaključno, ovarijektomija značajno utječe na izražaj brojnih gena uključenih u različite biološke procese, što potvrđuje pretpostavku da mnogi molekularni putovi imaju važnu ulogu u patofiziologiji osteoporoze.

KLJUČNE RIJEČI: DNA-čip, koštana razgradnja, osteoporoza, ovarijektomija

\section{CORRESPONDING AUTHOR:}

Prof. dr. sc. Slobodan Vukičević

Department of Anatomy

Medical School, University of Zagreb

Šalata 11, HR-10 000 Zagreb, Croatia

E-mail:vukicev@mef.hr 